\title{
USING MULTIMEDIA PRESENTATION IN THE FOREIGN LANGUAGE CLASSROOM TO FORM TERTIARY STUDENTS' ORAL PRESENTATION COMPETENCE
}

The article deals with the problem of learner-centered approach, one of the main educational strategies, involving the use of creative method in teaching foreign languages. Till date, foreign language educators involved in teaching language and communication to tertiary students in the context of the New Ukrainian School paradigm face an uphill task in developing future professionals' communicative competence. The special accent in the research is done on the benefits of implementing effective presentation skills and communicative competence as important developmental qualities for future professionals' learning. Yet identifying the definitive qualities and methods to practice those skills has had minimal emphasis in current education programs. In addition to traditional abilities such as making clear presentations, speaking well, articulating some arguments, students are faced with an explosion of options for organizing and presenting information using multimedia technologies.

The fundamental belief underlying this article is that the goal of implementing multimedia into foreign language educational contexts is to exploit the attributes of multimedia technologies in order to support deeper, more meaningful student-centered learning and to develop undergraduate students' communicative competence. In view of this, the use of students' presentation skills is perceived to be significant in the development of communicative competence. We attempt to analyse the notion of oral presentation competence (henceforth OPC), as a life-ability complex to mobilize and deploy a communication immediacy and multimedia technology literacy in order to respond appropriately and effectively to the modern demands and learning environment challenges presented by foreign language communicative context in countless real-life situations and interactions. The main integrative components of OPC were identified.

The challenge of tertiary students' foreign language OPC formation is accentuated by apparent lack of effective activities aimed at forming a set of OPC skills. One of the most effective ways to do this is to develop a series of activities to form OPC during introduction and conclusion presentation stages by means of multimedia presentation (henceforth $M M P)$. In this medium the communication will be richer simultaneously engaging both the auditory and visual faculties of the audience. It results not only in increased attention levels and meaningful absorption of the presented information, but also in retention of the information by the audience.

The MMP is viewed as one of the effective learnercentered activities that can be used in the language classroom as an effective tool for improving students' foreign language OPC. It is aimed at foreign language speaking skills and based on development of the given competence that can be applied with the purpose of improving tertiary students' 21st century “life-skills". The examples of students' Power Point slides performance are being considered.

Key words: oral presentation competence; opening techniques; closing techniques; multimedia presentation; PowerPoint software. кандидат педагогічних наук, доцент, доцент кафедри германських мов, Київський національний лінгвістичний університет, alla-i@ukr.net

\section{МУЛЬТИМЕДІЙНА ПРЕЗЕНТАЦІЯ НА ЗАНЯТТІ 3 ІНОЗЕМНОЇ МОВИ В ПРОЦЕСІ ФОРМУВАННЯ УСНОÏ ПРЕЗЕНТАЦІЙНОÏ КОМПЕТЕНТНОСТІ СТУДЕНТІВ ЗАКЛАДІВ ВИЩОЇ ОСВІТИ}

Стаття присвячена проблемі застосування особистісно-орієнтованого підходу в навчанні іноземних мов студентів закладів вищої освіти 21-го сторіччя. Такий підхід визначається як один з основних освітніх стратегій, що наповнений креативними методами викладання, i, таким чином, забезпечує формування усної презентаційної компетентності (УПК) студентів закладів вищої освіти. Це поняття визначено як комплексну "життєво необхідну" здатність мобілізувати та застосовувати комунікативну безпосередність та мультимедійну грамотність задля того, щоб відповідати вимогам сучасного світу та викликам іншомовного комунікативного середовища в незліченній кількості ситуацій та інтеракцій.

Визначено основні інтегративні складники формування УПК. Особливий акцент у дослідженні зроблено на основних перевагах застосування презентаційних умінь, а також труднощах, що виникають під час проведення усної презентації на занятті з іноземної мови в університеті.

Фундаментальне положення цієї статті полягає в тому, що основною метою використання мультимедійної презентації (ММП) в іншомовному освітньому середовищі $\epsilon$ застосування мультимедійних технологій задля підтримки значущого студентоцентрованого навчання та розвитку іншомовної комунікативної компетентності студентів. З огляду на це, формування та розвиток презентаційних умінь студентів розглядається як важливий елемент у розвитку комунікативної компетентності, що має стати значущим як для учасників, так і для практикуючих.

Приклади завдань щодо формування УПК студентів на вступному та завершальному презентаційних етапах наведено англійською мовою. Такий набір завдань спрямований реалізувати високу іншомовну активність та розвинути основні вміння студентів у світлі використання ММП з програмним забезпеченням PowerPoint.

Ключові слова: усна презентаційна компетентність; техніка вступного презентаційного етапу; техніка 
завершального презентаційного етапу; мультимедійна презентація; програмне забезпечення PowerPoint.

Мельник Алла Ивановна, кандидат педагогических наук, доцент, доцент кафедры германских языков, Киевский национальный лингвистический университет, alla-i@ukr.net

\section{МУЛЬТИМЕДИЙНАЯ ПРЕЗЕНТАЦИЯ НА ЗАНЯТИИ ПО ИНОСТРАННОМУ ЯЗЫКУ В ПРОЦЕССЕ ФОРМИРОВАНИЯ УСТНОЙ ПРЕЗЕНТАЦИОННОЙ КОМПЕТЕНТНОСТИ СТУДЕНТОВ УНИВЕРСИТЕТОВ}

Статья посвящена проблеме применения личностно ориентированного подхода в обучении иностранных языков студентов университетов 21-го века. Такой подход рассматривается как одна из основных образовательных стратегий, наполненная креативными методами преподавания, и таким образом, обеспечивающая формирование устной презентационной компетентности (УПК) студентов университетов. Данное понятие определяется как комплексная “жизненно важная" способность мобилизировать и использовать коммуникативную непосредственность и мультимедийную грамотность для того, чтобы отвечать требованиям современного мира и вызовам иноязычной коммуникативной среды в бесчисленном количестве ситуаций и интеракций.

Особенный акцент в исследовании сделано на основных преимуществах использования презентационных умений, а также трудностях, которые возникают во время проведения устной презентации на занятиях по иностранномуязыкув университете. Определены основные интегративные составляющие формирования УПК.

Фундаментальным положением данной статьи есть то, что главной целью использования мультимедийной презентации (ММП) в иноязычной образовательной среде есть внедрение мультимедийных технологий для поддержания студентоцентрированного обучения и развития иноязычной коммуникативной компетентности. В связи с этим, формирование и развитие презентационных умений рассматривается как важный элемент в развитии коммуникативной компетентности, что должно стать значимым как для участников, так и для практикующих.

Примеры заданий для формирования УПК студентов на вступительном и завершающем презентационных этапах приведены на английском языке. Такая система направлена на реализацию высокой иноязычной активности и развитие "жизненно важных" умений студентов с использованием ММП с программным обеспечением PowerPoint.

Ключевые слова: устная презентационная компетентность, техника вступительного презентационного этапа, техника завершающего презентационного этапа, мультимедийная презентация, программное обеспечение PowerPoint.

Introduction. New rethinking of foreign languages training in the context of New Ukrainian School reform processes is stipulated by the up-to-date practical demand for culture-correspondence renovation of professional education essence that is oriented to the world's progressive standards. Reforming foreign language teaching Ukraine has a great influence on the process of updating the educational system in general and the development of academic literacy at university, which is associated with the creation of new educational norms, modernizing of curricula and educational and teaching material content. In recent Ukrainian state documents on educational policy, there was confirmed the considerable shift from traditional learning to student-centered educational technologies that raise the responsibilities of students for their learning results.

The relevance of this paper has to be taken for granted, since the problem of teaching tertiary students, its development and realization are the most significant goals of communities aimed at the future educational horizons. In view of this, there is a high necessity to create and implement the student-centered activities that would allow students to become really active participants in learning foreign languages and cultures (Melnyk, 2016).

In a majority of language based courses tertiary students, who are preparing for the working medium, are aware of the impact of competent presentation skills in the foreign languages. Going into details, for the students studying foreign languages to succeed in the university environment, and in their future work purposes, it is important to be able to express their ideas clearly in English as well as develop the skills and confidence in giving oral presentations. Although there are more students enrolling in oral presentation activities, most of them are unaware of what to be done to improve their oral presentation skills.

Conducting an oral presentation (henceforth OP) is a key feature of various courses and disciplines in higher education institutions as well as one of the most fruitful sources of personal growth in students' tertiary tutelage. They may take the form of a short or long presentation at a seminar or tutorial, delivered either individually or as a part of a group. It is similar to the process of writing an essay, except students need to be mindful of a live audience. Yet, giving a presentation is an endeavor for the students at the tertiary level of education. Lecturers assume that many tertiary students end up hyperventilating with the thought of having to stand in front of their peers to make an OP. Many students consider it as one of the most challenging forms of assessment in the university (Alwi, 2013).

What is more, using an OP in the classroom is a time-consuming activity. For this reason, presentations are often not used in foreign language classes or are only used as one-time summative assessment at the end of the course, with very little class time spent on getting 
the students ready to present. The result of this is that students often do not find the presentations to be a positive learning experience.

One of the issues, facing modern Ukrainian university students today, is that very few students, standing in front of their peers, give their presentations properly. While secondary school teachers seem to recognize the benefits of having their students engaged in communicative activities, at times they are under extreme pressure to prepare their students for the B1 and/or B2 levels of the Ukrainian school-leaving examinations in English (Independent External Evaluation (ZNO)), which often results in their focusing on vocabulary, reading, listening, use of English writing and speaking is left by the wayside (Melnyk, 2019).

Currently a lot of research has been done on the problem of learner-centered approach, as one of the main educational strategies, involving the use of creative methods in teaching foreign languages and cultures to tertiary students. Foreign language educators involved in teaching language communication to tertiary students face an uphill task in developing future professionals' communicative competence with competent presentation skills.

Plenty of foreign language teaching materials now include prompts and activities designed to foster students' oral presentation skills. While working with tertiary students, one question tends to show up when the heading "oral presentation" appears on the page is: what is oral presentation, anyway? The problem is that $\mathrm{OP}$ is treated as if it is actually a language skill, whereas in fact it is a complex life-skill, which, if properly developed can benefit students in countless real-life situations and interactions.

The special accent in the research is done on the benefits of implementing effective presentation skills and communicative skills as important developmental qualities for future professionals' learning. Yet identifying the definitive qualities and methods to practice those lifeskills has had minimal emphasis in current education programs. In addition to traditional abilities such as making clear presentations, speaking well, articulating some arguments, students are faced with an explosion of options for organizing and presenting information using multimedia technologies. However, there are limited publications on the students' options for organizing and presenting information using multimedia technologies. Basic textbooks are not sufficiently aimed at boosting their oral presentation skills in higher education environment, which necessitates the revision of the foreign language teaching content.
In view of the lack of opportunities to practice oral presentations during foreign language classes, it is necessary to develop students' communication immediacy and presentation skills in order to respond appropriately and effectively to the demands, challenges and opportunities presented by foreign language communicative context. The goal of implementing multimedia into foreign language educational contexts may yield its benefits - to exploit the attributes of multimedia technologies in order to support deeper, more meaningful student-centered learning and to develop undergraduate students' communicative skills. Thus, the issue of activities for developing tertiary students OPC by means of MMP is relevant and up to date.

Literature review. The emergence of new teaching tools based on computer technologies has made the modern educational process multidimensional. The advent of World Wide Web (WWW) and communication technologies has opened a vast array of possibilities for the use of multimedia technologies to enrich the learning environment. Up to date, multimedia technologies are the most promising and popular teaching information means that help to create entire images collections, texts and data that are accompanied by sound, video, animation and other visual effects (Buzduhan, 2015). The use of such technologies in educational institutions is seen as necessary for keeping education relevant to the 21 st century (Selwyn, \& Gordard, 2003).

The issue of creation and implementation of multimedia technologies into education and teaching foreign languages is being actively developed by E. Arvanitopulo, V. Bykov, R. Hurevych, A. Hurzhii, T. Koval, E. Litvinova, N. Mayer, E. Polat, O. Spivakovskii, P. Sysoyev, V. Titova, O. Ustymenko, et al. The scientists seek to understand the issue of multimedia technology use in methodological aspects, to classify modern technologies and to describe them, as well as the stages of project work and the typology of educational projects. Only few studies have attempted to examine that reciprocal preferences resulting from an expanding usage of multimedia technologies were increasingly to be found in justification with presentation preferences.

Plenty of foreign language teaching materials now include prompts and activities designed to foster students' oral presentation skills. It has been explored by several researchers, among them: Ang, \& Mariam, 2014; Barrett, \& Liu, 2016; Hovane, 2009; Maiier, 2018; Otoshi, \& Heffernen, 2008; Ustymenko, 2014, 2016. All these studies are valuable in their own way. A 
lot of them were conducted on English as foreign language learners in foreign context.

Evidence from several research studies indicates that MMP is a tremendous tool in presenting information in different ways. It can be presented through different forms, such as presentations accompanied by audiovisual aids, which can make it more interesting and lively. The learners feel more active so as to learn various topics because they learn by applying the technology to a task rather than by being directly "instructed" by the technology (Grabe, \& Grabe, 2005).

In the medium of MMP the communication will be richer simultaneously engaging both the auditory and visual faculties of the audience. It isn't only result in increased attention levels and meaningful absorption of the presented information, but also in the retention of the information by the audience.

Recognizing the importance of MMP, many presentation tools such as PowerPoint have been developed to facilitate creation of effective presentations. These programs enable students to present their ideas in the form of slides utilizing text, sound, pictures and video. However, many studies have acknowledged that such technology tools are not utilized to their full potential (Adib, 2010).

There are very limited studies that examined detailed effective techniques in the area of OPC formation of tertiary students along with MMP. In giving effective MMP in a foreign language, it is not a simple matter of learning language and following instructions, rather it is an ability requiring process of complex technology aspects as well as linguistic understanding. Tertiary students, especially foreign language students need to acquire technology understanding to learn oral presentation skills. Without these, the students are unable to use language effectively to interact with the audience appropriately. Simultaneously, mere accessibility of technologies and simplification of tools in the learning process are not enough to guarantee creation of effective MMP.

The article purpose was to make up the series of activities aimed at forming tertiary students' OPC by means of MMP. This study was conducted with the aim to fulfil the following objectives: to focus on studies on MMP and outline some of the benefits of implementing presentation skills in the foreign language classroom as well as some of the difficulties involved in using MMP in university language medium; to lay out main skills of OPC and main stages of its formation; to examine techniques on helping students develop OPC and organize the MMP on the issue they have investigated; to present a series of activities aimed at forming OPC in the English classroom by means of presentation in a way that is beneficial for both the participants and the practitioners.

Discussion. The need to develop communicatively competent students is determined as one of the key educational strategies in Ukraine. It involves the use of creative, problem-based, research, interactive, presentational teaching methods for equipping students with effective communication skills. The concept of effective communication skills is synonymous with the notion of communicative competence.

The term "competence" can be used in many ways, including its casual everyday use as a synonym for "ability", its more technical use within vocational training, and its use to denote the ability to meet complex demands within a given context. For the purpose of the current positon, the term "competence" is defined as "the ability to mobilize and deploy relevant values, attitudes, skills, knowledge and understanding in order to respond appropriately and effectively to the demands, challenges and opportunities that are presented by a given type of context".

Communicative competence is associated with learner's adaptation of a communication situation by demonstrating skills in appropriate knowledge relevant to communication situation and context (Lailawati, 2008). As Bhattacharyya (2012), Dannels (2009) indicated, among the sub-sets of communicative competence there should be some communication immediacy that suggests use of interactive language, visual language, analogies and humorous experiences to create the sense of connectedness with the audience.

It is important to use a clear, step-by-step method for teaching presentations in English classes. It is not enough to simply tell students to go and make a presentation. Students have to be taught the skills involved in giving a presentation and effective techniques to organize the presentations on the issue they have investigated. Consequently, communicative competence is associated with the demonstration of students' monologue communicative skills, knowledge and abilities particularly to a communicative context where oral presentation cases are one such type of context.

Oral presentation is the process of presenting understanding of the topic to an audience. It is typically a demonstration, introduction, lecture, or speech meant to inform, persuade, inspire, motivate, or to build good will or to present a new idea. Within the English language course and discipline-based courses offered at university, the OP is used as part of present research projects or the assessment (Zareva, 2011; Duff, 
2010). Ming (2005) defined OP as 'partly spoken and partly visual form of communication' (p. 118) which usually has a time limit and happens in organizational settings. As Kuldip (2018) admitted OP help students to develop and integrate soft skills such as presentation skills.

Consequently, we consider OP as a formal, structural and systematic kind of a talk, requiring preparation. It is more than just reading a paper or set of visual aids to an audience and it is more than just standing up and giving information. Presentation skills are necessary for professional and personal development as well as formation of foreign language communicative competence. The presentations may describe, narrate, persuade or communicate ideas.

There are enormous benefits of OP as shown in the literature. Firstly, among them is the use of four language skills (King, 2002). It prepares students for real life in the future. King (2002) adds that OPs are shown to help bridge the gap between language study and language use; presentations require students to use all the skills in a naturally integrated way, to encourage students to become autonomous learners.

Secondly, OP is shown to be extremely successful with respect to improving students' skills as well their autonomy. Girard, Pinar, \& Trapp (2011) found that OP leads to better group interaction and participation. OP requires the students, who are giving a presentation, to use only English to communicate to one or more interlocutors. Additionally, OP can enhance confidence (King, 2002), providing authentic practice of English and improving students' communication skills.

We are aware of the various benefits which OP can provide in the foreign language learning. Particularly, it allows students to engage in a cooperative task that requires them to use a foreign language to explain their ideas and to negotiate meaning with a larger community of language learners while they are planning and practicing their presentations.

$\mathrm{OP}$ in the classroom promotes learners to use foreign language to communicate with others in a natural way, thinking beyond the measures of book, taking initiative to use language interactively and meaningfully. If OPs are not set up correctly, the difficulty of the tasks involved in presenting in front of others can take away from the didactic and pedagogical benefits of using presentations in the classroom. In such scenario, it is important that the foreign language teacher understands the student's skills involved in giving presentations, and the potential difficulties OP can present.

For the purpose of this study, it is important to comment on multimedia skills necessary for tertiary students involved in oral presentations. Some studies (Bhattacharyya, 2012; Robinson, 2005), which reveal varying competency requirements among tertiary students, suggest that prospective graduates should possess technical competence that refers to application of technical knowledge through use of multimedia techniques. Technical competence is associated with multimedia competence along with learner's mastery of technical content and application of such knowledge in relevant communicative situation and context.

Multimedia may be considered as the integration of the human senses into a computer environment for the purpose of improving communication between the computer and its user, and among the users (Moore, 1994, pp. 275-324). A multimedia instruction message is a presentation consisting of words and pictures that are designed to foster meaningful learning.

Multimedia techniques can be used to support students while they are developing their presentations and it can be useful as part of the presentations themselves. For example, students combine their OP with audio, images, diagrams, photographs, animation and/or video. They create their presentations using Power Point slides, online outlines, maps. A multimedia presentation contains some form of media or animation. Typically a multimedia presentation contains at least one of the following elements: video, animation, sound (this could be a voice-over, background music, sound clip).

Multimedia technology competence is the ability to mobilize and deploy relevant technical skills in order to respond appropriately and effectively to the demands, challenges and opportunities by multimedia technology context. The use of multimedia such as Power Point software, videos, images and pictures needs to be exploited in the classroom as much as possible in order to effectively expose foreign language learners to the target language. For that reason a great tendency towards the use of MMP and its integration into the curriculum, developed by foreign language teachers, has gained a bulk importance.

We still support the claim that most tertiary students are not being taught how to conduct MMP effectively. This lack of familiarity with this presentation causes them to feel embarrassed, uncomfortable and shy. If such communicative activity is not properly prepared, participating cannot provide students with a necessary learning experience that would allow them to interact with others using only their foreign language competence. Furthermore, MMPs that are not set up correctly can be too difficult for students to do effectively and this creates a learning environment that is not conducive to foreign language competence 
formation. An example of the worst-case scenario is where the presenter stumbles through his long and formally written presentation speeches while the rest of the group would find themselves drifting off.

The fundamental belief underlying this article is that the goal of implementing MMP into foreign language educational contexts is to exploit the attributes of multimedia technologies in order to support deeper, more meaningful learner-centered learning. In view of this, use of students' presentation skills is perceived to be significant in the development of communicative competence. A fundamental principle of our investigation is an idea that an educational system, which equips students with such competences, empowers them, endowing them with capacities which they need to become active competent participants in learning and curriculum context, and the ability to function as autonomous learners capable of choosing and pursuing their communicate goals and skills to their fullest potential.

The given research indicates that $\mathrm{OPC}$ is a unique supplementary complex accompanied by communicative skills and a way in which some shown, arranged, explained ideas help learners choose the suitable multimedia skills and effective techniques used to make their audience understand the flow of the text and develop their public speaking skills. Literature review results indicate that the essential interdependent components of OPC among tertiary students are, namely, communication immediacy and multimedia technology literacy. Moreover, we assume such immediacy is more than just a talent, it's a communicative competence that can be learnt and developed in a meaningful multimedia context.

Thus, OPC is a complex life-ability to mobilize and deploy a communication immediacy and multimedia technology literacy in order to respond appropriately and effectively to the modern demands and learning environment challenges presented by foreign language communicative context in countless real-life situations and interactions. One of the most effective ways to form a set of OPC skills is MMP. In the medium of the given presentation the communication will be richer simultaneously engaging both the auditory and visual faculties of the audience. It isn't only result in increased attention levels and meaningful absorption of the presented information, but also in the retention of the information by the audience.

In this way, we propose a proper model of OPC which enables tertiary students to participate effectively in the foreign language communication. The key purpose is to describe the skills of OPC which need to be acquired by learners if they are to become effective participatory learners. Thus, to be considered competent, a set of OPC skills must be displayed.

The main communication immediacy skills are the following:

1. Skills of the OP type identification and its aim. There are different types of presentations: informative (e.g. university presentations, science and technology presentations, business seminars); persuasive (e.g. debates, to a group of peers, political speeches); ceremonial (e.g. graduation, award ceremonies (presenting or receiving), anniversaries, commemorations etc.). Ceremonial speeches are designed and delivered to mark the importance of a ceremony, festivity or special event (weddings, award ceremonies (presenting or receiving), commemorations etc.

MMP are given to describe an invention, a place, people (e.g. a famous explorer, a demanding profession, a landmark, a place of great beauty in your country); narrate an experience, a story, a myth, a fable, a legend, an experience (e. g. a natural disaster, a backpack incident, a world mystery); persuade by presenting arguments for and against an issue, expressing student's opinion on an issue, stating a problem and suggesting solutions etc.

2. Skills of MMP organization with a clear structure of the essential elements. Generally, it should be comprised of three parts: introduction, main body (main message) and conclusion. This study will range only over introduction and conclusion parts as the subject matter.

In the introduction students have to greet the audience and present themselves and the topic through a variety of opening techniques:

1) Address the audience by asking a general question, e.g. When I say earth, air, fire and water, what comes to mind? How many types of personalities do you think there are?

2) Use a quotation or saying, e.g. As Nelson Mandela, President of South Africa said "Character is like a tree and reputation like its shadow. The shadow is what we think of it, the tree is the real thing", and I couldn't agree more. Personality is not categorical. It is dimensional.

3) Ask a rhetorical question, e.g. The theory of four types of personality can't really develop an understanding of different people, can it?

4) Make a statement, e.g. The theory of fluids achieved great success and dominated Western thinking for over two thousand years until the 1700s, when physicians proposed the idea that people's moods were affected by chemicals in the blood. 
5) Narrate a personal or general story, e.g. The ancient Greek physician Hippocrates believed that human emotions were caused by fluids in the body, which he called 'humors'. According to him these humours were responsible for the health and personality of an individual. He divided them into four categories: choleric, sanguine, melancholic and phlegmatic. This was the beginning of the fluid theory.

6) Set the scene and stimulate emotions, e.g. Close your eye and picture this: there are lots of people all around you. Some are fiery personalities who get angry easily but are also passionate and outgoing, others are imaginative as they dream a lot and are very emotional, other people are practical, who are well grounded and think things through and finally, people who are analytical, they are intellectual and use their minds in situations.

7) Use a rhyme or a short poem, e.g.

Self-centered tend to be impulsive

Role models - are agreeable enough

Reserved are thought to be well trusting

And Average are open less to abstract life!

9) Use humor (a joke, a riddle etc.), e.g. This personality is the one who likes to have every 'I' dotted and every ' $t$ ' crossed. Punctuality and order is of prime importance to them. What personality type is it?... A melancholic individual.

In conclusion the main points are being summarized, students invite and answer the questions from the audience and thank the audience for listening through the closing techniques, not only addressing the audience by asking a question, using a quotation /saying, ask a rhetorical question, making a statement, narrating a personal or general story or using humor (a joke, a riddle etc), using a rhyme or a short poem, but actively use a 'what if' question technique.

One more fundamental belief underlying this article is that the Cone of Edgar Dole guides students in making suitable multimedia technical tools selection with regard to retention of information during MMP performance. It is evident that a learning experience which involves higher involvement of the audience results in better retention of information presented. With the passive level of involvement in learning process $30 \%$ of what we see we tend to remember. $50 \%$ of what we see and hear, $50 \%$ we clearly remember. When we depict the active participation in giving a talk, doing a presentation, simulating a real experience, $90 \%$ of what we say and do we tend to remember.

According to the studies in the literature it is evident that in MMP a significant component is visuals, as presenters are expected to deliver their speech using MMT such as Power-Point or Keynote software, videos, images and pictures (Bloch, 2013). This way a presenter can support and highlight his message, and make the whole MMP more invigorating. The basis of the teaching tertiary students oral presentation skills using MMT are principles of long-term benefits at each stage, the students approach their cognitivecommunicative research from viewing, perceiving audio-visual materials to their analysis, making their own statements.

The following multimedia technology literacy skills are:

1. Skills of using visuals (short video clips, photos, charts, films, pictures etc.). These can help set the scene for the topic you are going to talk about. For instance, you can search for video clips on websites such as YouTube, e.g. Find your temperament! Explaining the 4 elements (Fire, Water, Earth and Air) and 4...

https://healthyshiningpeople.wordpre

https://www.herothink.com

https://en.m.wikipeda.org

2. Skills of using music (a sound, soundtrack etc.), e.g. Listen to the four music extracts "Four Seasons" by Vivaldi. Which best matches each personality type? For instance, you can search for video music extracts on sites such as You Tube on the Internet.

https://amzn.to/1I2dNNu

https://www.youtube.com/playlist?list

https://youtu.be/WwkTuq4pxE0

https://youtu.be/G1yEyHqc2eU

As the most common visual mode is the use of Power Point slides, we offer some examples of students' Power Point slides performance on the topic "Modern Technologies" along with some recommendations to engage audience's attention:

- Use a simple layout, as it will help the audience to follow the presentation easily.

Slide 1

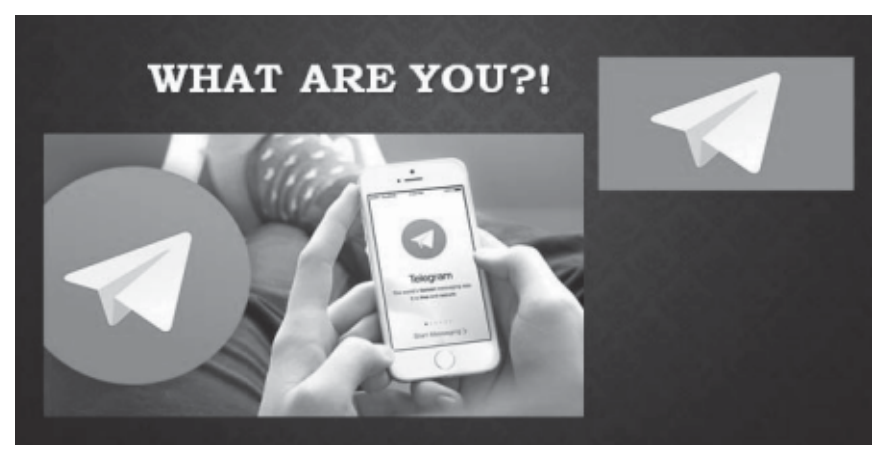


- Use a title in order to let the audience know what a presenter is speaking.

Slide 2

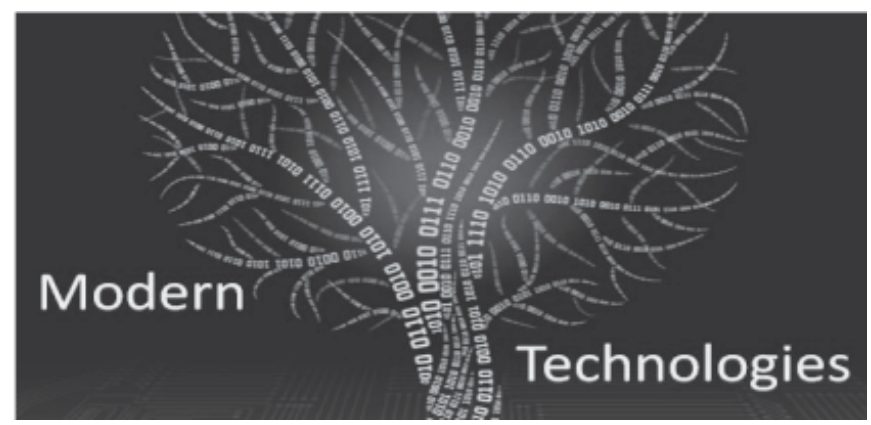

- Use dark fonts on light backgrounds or light fonts on dark backgrounds.

\section{Slide 3}

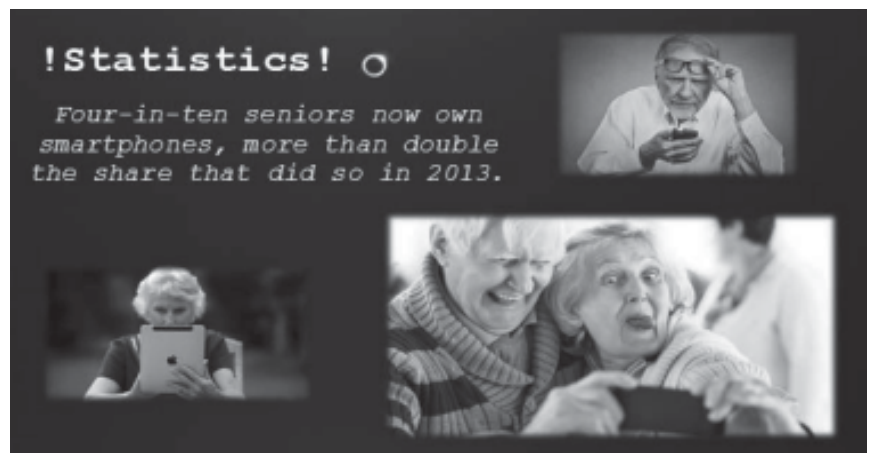

- Use clear and easy-to-read fonts.

Slide 4

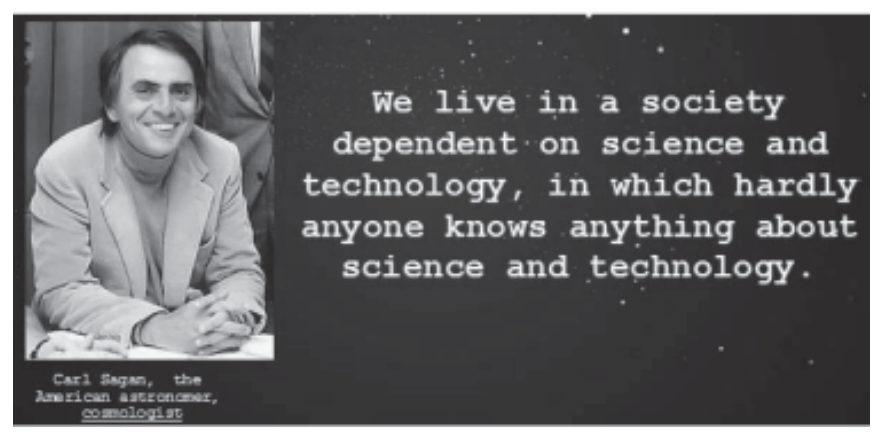

- Use notes rather than long sentences. The slides are a visual aid, not a reading text.

Slide 5

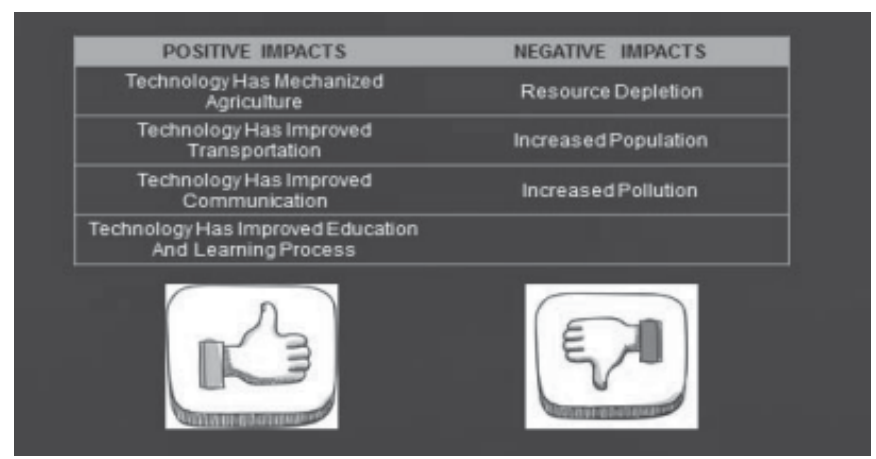

The key thing in forming the OPC of tertiary students is developing two groups of activities aimed at forming tertiary students' OPC skills in the introduction and conclusion presentation stages. This series of activities is created in accordance with the concept of teaching methods, which is based on productive and creative means of knowledge acquisition and development of skills of oral speech taking into account the opening and closing techniques.

During the development of our experimental methodology students were offered the first type of activities with the opening techniques, giving a presentation about dealing with the "Personality types and characters".

Activity 1. Read the extracts (A-B) from the introductions of presentations and match them to the opening techniques (1-2).

\section{Addressing the audience}

If we are all so unique, why is it that we are always trying to sort people by personality type? From the beginning of time, man has been putting people into categories by analyzing their similarities as well as differences. The number and variety of classifications of personality types is impressive to say the least.

\section{Setting the scene and stimulate emotions}

Have you ever wondered why some people express their ideas or opinions with confidence, while others seem to be insecure? Or rather, have you noticed that some people seem to be happy and energetic all day while others may seem to be less energetic and engaged?

Activity 2. Read the extracts (A-B) from the introductions of presentations and match them to the opening techniques (1-2).

\section{Making a statement}

No one can tell just how the theory of fluids described by Hippocrates might affect our life in the future, but I hope its roots will develop modern-day categories, this would help people to predict how other people may behave in certain situations.

2. Stimulating emotions and asking a rhetorical question

The four personality types share some characteristics, don't they? Well, studying personality temperaments may not be a pure science. We can't really classify personalities into types but there are a number of key qualities that many people share. 
Activity 3. Read the extracts (A-B) from the introductions of presentations. Match them with the techniques (1-2).

1. Using appropriate visuals

Look at these pictures. Describe their personalities using as many adjectives as you can. What type of personality do you think they have?

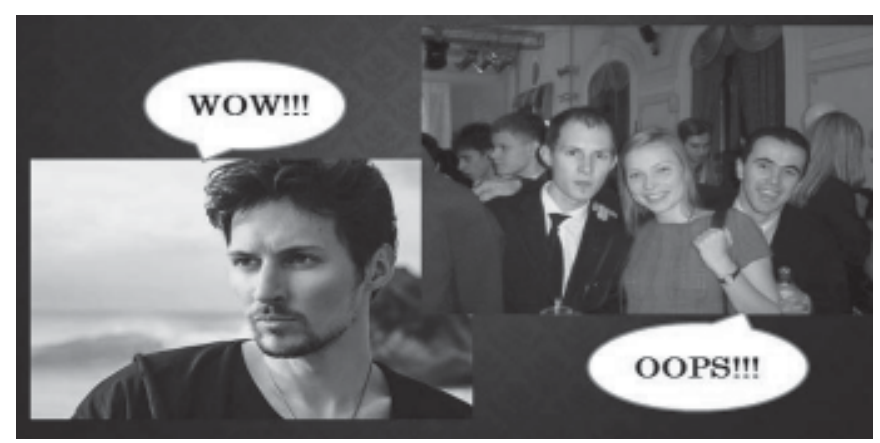

2. Narrating a personal story

I have a sarcastic sense of humor that not everybody gets. Sometimes, I can be too over cautious in situations. I'm certainly a forgetful person, I'm really bad at remembering things, but I also think that I'm courageous and like to go for things because I'm energetic, too.

During the development of our experimental methodology students are offered the second group of activities with the closing techniques, giving a presentation about dealing with "The fear of public speaking.“

Activity 1. Read the extracts (A-B) from the conclusions of presentations. Match them to the closing techniques (1-2) 1 asking a 'what if' question 2 using a rhyme

A. What if everyone with fright used these tips? I'm sure they would feel much better!

B. So remember this:

If you feel fear and sweaty once in a while

Listen to my golden rule to keep calm.

If practice makes perfect

And perfect needs practice,

You are perfectly practiced

And practically perfect.

Activity 2a. Read the extracts (A-C). Which are from the introductions of presentations? Which is from the conclusion: 1) addressing the audience asking a 'what if' question, 2) setting the scene and stimulating emotions; 3) asking a 'what if' question and making a statement.

A. Imagine this: You have just received your examination schedule and it's totally hectic. You can feel a headache coming on, your heart is pounding in your chest and you also feel overwhelmed and frustrated. These could be the initial signs of stress, but what you don't know is that some stress might in fact be doing you some good.

$B$. What if we could all embrace stress and realize that it is a normal part of our daily lives? Well, life would certainly be much easier this way.

C. Did you know that the survey you took part in last week showed $45 \%$ of you feel tired because of stress? Isn't this a staggering percentage? Let's see what this means and what you can do about it.

Activity 2b. Match the extracts (A-C) to the opening / closing techniques (1-3).

Conclusion and further research prospects. If any conclusions may be drawn from the above data, we pay attention to the integrative principle of teaching foreign languages and consider a communicative method using MMP as one of the ways to develop OPC as well as autonomy of the student from the teacher in the process of English learning. In addition, the given investigation contributes to the formation of students' creativity, improves their self-esteem. We focus on an MMP, as its communicative orientation makes it possible to actively apply such lingual-methodical principles of the communicative approach as practical orientation, students' motivation, autonomous learning skills.

Consequently, this study was focused on OPC and its main components - communication immediacy and multimedia technology literacy. Some of the benefits of implementing MMP in the foreign language classroom as well as some of the difficulties involved in using presentations at university language medium were outlined. Effective techniques guidance on how to help students develop the actual OPC skills are being shown.

Our methodology is aimed at developing the acquired knowledge of oral speech, taking into account new achievements in improving the communicative skills of tertiary students, accompanied by MMP. The peculiarities of our method include the combination of communicative and information-technology approaches in the teaching English oral speech. It is hoped that the pedagogical and methodological ideas outlined in this paper, can help teachers in EFL classes effectively employ MMP as a means of improving their students' OPC.

Henceforth, this study implies that it is important for educators, especially language teachers to work towards further understanding their students' OPC. What is more pertinent, various courses and disciplines 
in institutions of higher learning must be constructed for students to create a better learning environment so that they can become effective presenters when they step into the working world. Future studies on OPC need to explore effective ways to get feedback from the audience during question-and-answer session.

\section{СПИСОК ПОСИЛАНЬ}

Буздуган, О. А. (2015). Використання мультимедійних засобів навчання в контексті осучаснення процесу викладання іноземної мови. Наука і освіта, 2, 10-15.

Майер, Н. В., \& Устименко, О. М. (2018). Практикум з методики використання сучасних засобів, методів $i$ технологій навчання іноземних мов і культур: навч.метод. посіб. для самост. роботи студентів магістратури. Київ: Ліра-К.

Мельник, А. І. (2016). Особливості формування професійно орієнтованої іншомовної компетентності студентів немовних вишів на основі особистісно-діяльнісного підходу. Наукові записки Національного університету «Острозька академія». Серія : Філологічна, 61, 186189.

Устименко, О. М. (2016). Дидактичні характеристики проектної технології навчання іноземних мов і культур. Взято з http://int-konf.org/ru/2016/suchasna-nauka-vmerezhi-internet-16-18-02-2016/1212-kandidat-pedagogichnikh-nauk-dotsent-ustimenko-o-m-didaktichnikharakteristiki-proektnoji-tekhnologiji-navcvhannyainozemnikh-mov-i-kultur.

Устименко, О. М., \& Коваленко, Ю. В. (2014). Комплекс вправ і завдань для навчання студентів другого курсу англомовного монологічного мовлення на основі проектної методики. Іноземні мови, 4, 20-32.

Adib HajBagheri, M. (2010). Bartsch effectiveness of power point presentation in lectures. Computers and Education, 41, 77-86. Retrieved from http://tums.isna.ir/Default. aspx?NSID $=5 \& S S L I D=46 \& N I D=444$.

Alwi, N. F., \& Sidhu G. K. (2013). Oral presentation: selfperceived competence and actual performance among UiTM Business Faculty students. Procedia - Social and Behavioral Sciences, 90, 98-106.

Ang, T. C., \& Mariam, M. (2014). A study of visual design in PowerPoint presentation slide and its relationship with postgraduate learner engagement and satisfaction International Conference on Society, Education and Psychology, Kuala Lumpur, Malaysia, 78(18), 91-96. http://doi.org/10.7763/IPEDR.2014

Bloch, J. (2013). Technology and English for specific purposes. In B. Paltridge \& S. Starfield (Eds.), The Handbook of English for Specific Purposes (pp. 385-401). Oxford, England: Wiley-Blackwell.

Barrett, N. E., \& Liu, G. Z. (2016). Global trends and research aims for English academic oral presentations: changes, challenges, and opportunities for learning technologies. Review of Educational Research, 20(10), 1-45. http:// doi.org/10.3102/0034654316628296

Bhattacharyya, E. (2012). Communicative competence: novice versus professional engineers' perceptions. Proceedings at ICSBS 2012: International Conference on Social and Behavioral Sciences, 6-7 December, Penang,
Malaysia. Retrieved from https://www.semanticscholar. org/paper/Communicative-Competence\%3A-Noviceversus-Engineers\%27-Bhattacharyya/03e4cf9a4ef59be 56ea07ac5296ea4133ebba123.

Dannels, D. P. (2009). Features of success in engineering design presentations: a call for rhetorical knowledge. Journal of Business and Technical Communication, 23, 399-427.

Duff, P. A. (2010). Language socialization into academic discourse communities. Annual Review of Applied Linguistics, 30, 169-192.

Girard,T., Pinar, A., \& Trapp, P. (2011). An exploratory study of class presentations and peer evaluations: do students perceive the benefits? Academy of Educational Leadership Journal, 15(1), 77-93.

Grabe, M. \& Grabe, C. (2005). Integrating technology for meaningful learning. USA: Houghton Mifflin.

Hovane, M. (2009). Teaching presentation skills for communicative purposes. Kansai University Foreign Language Education Forum, 8, 35-49.

King, J. (2002). Preparing EFL learners for oral presentations. Dong Hwa Journal of Humanistic Studies, 4, 401-418.

Kuldip, K., \& Afida, M. A. (2018). Exploring the genre of academic oral presentations: a critical review. International Journal of Applied Linguistics \& English Literature, $7(1), 152$.

Lailawati, M. S. (2008). Communicative competence: a Malaysian perspective. Human Communication: A Publication of the Pacific and Asian Communication Association, 11(3), 303-312.

Mel'nyk, A. I. (2019). Oral presentation in the foreign language university medium. Матеріали Міжнародної науково-практичної конференції «Ad orbem per linguas. До світу через мови», м. Київ, КНЛУ, 20-22 березня, 2019. Київ: Вид. центр КНЛУ, 551-553.

Ming, X. Z. (2005). Developing oral presentation skills in ELT classroom. CELEA Journal, 28(2), 118-120.

Moore, D. (1994). Multimedia presentation techniques and technology. Control and Dynamic Systems, 62, 275-324.

Otoshi, J., \& Heffernen, N. (2008). Factors predicting effective oral presentations in EFL classrooms. Asian EFL Journal, 10(1), 65-78.

Robinson, M. A., Sparrow, P. R., Clegg, C., \& Birdi, K. (2005). Design engineering competencies: future requirements and predicted changes in the forthcoming decade. Design Studies, 26, 123-153. http://doi:10.1016/j.destud.2004. 09.004

Selwyn, N., \& Gordard, S. (2003). Reality bites: examining the rhetoric of widening educational participation via ICT. British Journal of Educational Technology, 34(2), 169-181.

Zareva, A. (2011). 'And so that was it': linking adverbials in student academic presentations. RELC Journal, 42(1), 515.

\section{REFERENCES}

Buzduhan, O. A. (2015). Vykorystannia multymediinykh zasobiv navchannia v konteksti osuchasnennia protsesu vykladannia inozemnoi movy. Nauka i osvita, 2, 10-15.

Maier, N. V., \& Ustymenko, O. M. (2018). Praktykum z metodyky vykorystannia suchasnykh zasobiv, metodiv $i$ tekhnolohii navchannia inozemnykh mov i kultur: navch. metod. posib. dlia samost. roboty studentiv mahistratury. Kyiv: Lira-K. 
Melnyk, A. I. (2016). Osoblyvosti formuvannia profesiino oriientovanoi inshomovnoi kompetentnosti studentiv nemovnykh vyshiv na osnovi osobystisno-diialnisnoho pidkhodu. Naukovi zapysky Natsionalnoho universytetu «Ostrozka akademiia». Seriia : Filolohichna, 61, 186-189.

Ustymenko, O. M. (2016). Dydaktychni kharakterystyky proektnoi tekhnolohii navchannia inozemnykh mov $i$ kultur. Retrieved from http://int-konf.org/ru/2016/suchasna-nauka-v-merezhi-internet-16-18-02-2016/1212kandidat-pedagogichnikh-nauk-dotsent-ustimenko-om-didaktichni-kharakteristiki-proektnoji-tekhnologijinavcvhannya-inozemnikh-mov-i-kultur.

Ustymenko, O. M., \& Kovalenko, Yu. V. (2014). Kompleks vprav i zavdan dlia navchannia studentiv druhoho kursu anhlomovnoho monolohichnoho movlennia na osnovi proektnoi metodyky. Inozemni movy, 4, 20-32.

Adib HajBagheri, M. (2010). Bartsch effectiveness of power point presentation in lectures. Computers and Education, 41, 77-86. Retrieved from http://tums.isna.ir/Default. aspx?NSID=5\&SSLID=46\&NID=444.

Alwi, N. F., \& Sidhu G. K. (2013). Oral presentation: selfperceived competence and actual performance among UiTM Business Faculty students. Procedia - Social and Behavioral Sciences, 90, 98-106.

Ang, T. C., \& Mariam, M. (2014). A study of visual design in PowerPoint presentation slide and its relationship with postgraduate learner engagement and satisfaction International Conference on Society, Education and Psychology, Kuala Lumpur, Malaysia, 78(18), 91-96. http://doi.org/10.7763/IPEDR.2014

Bloch, J. (2013). Technology and English for specific purposes. In B. Paltridge \& S. Starfield (Eds.), The Handbook of English for Specific Purposes (pp. 385-401). Oxford, England: Wiley-Blackwell.

Barrett, N. E., \& Liu, G. Z. (2016). Global trends and research aims for English academic oral presentations: changes, challenges, and opportunities for learning technologies. Review of Educational Research, 20(10), 1-45. http:// doi.org/10.3102/0034654316628296

Bhattacharyya, E. (2012). Communicative competence: novice versus professional engineers' perceptions. Proceedings at ICSBS 2012: International Conference on Social and Behavioral Sciences, 6-7 December, Penang, Malaysia. Retrieved from https://www.semanticscholar.org/paper/Communicative-Competence\%3ANovice-versus-Engineers\% 27 - Bhattacharyya/ 03e4cf9a4ef59be56ea07ac5296ea4133ebba123.

Dannels, D. P. (2009). Features of success in engineering design presentations: a call for rhetorical knowledge. Journal of Business and Technical Communication, 23, 399-427.

Duff, P. A. (2010). Language socialization into academic discourse communities. Annual Review of Applied Linguistics, 30, 169-192.

Girard,T., Pinar, A., \& Trapp, P. (2011). An exploratory study of class presentations and peer evaluations: do students perceive the benefits? Academy of Educational Leadership Journal, 15(1), 77-93.

Grabe, M. \& Grabe, C. (2005). Integrating technology for meaningful learning. USA: Houghton Mifflin.

Hovane, M. (2009). Teaching presentation skills for communicative purposes. Kansai University Foreign Language Education Forum, 8, 35-49.

King, J. (2002). Preparing EFL learners for oral presentations. Dong Hwa Journal of Humanistic Studies, 4, 401-418.

Kuldip, K., \& Afida, M. A. (2018). Exploring the genre of academic oral presentations: a critical review. International Journal of Applied Linguistics \& English Literature, 7(1), 152.

Lailawati, M. S. (2008). Communicative competence: a Malaysian perspective. Human Communication: A Publication of the Pacific and Asian Communication Association, 11(3), 303-312.

Mel'nyk, A. I. (2019). Oral presentation in the foreign language university medium. Materialy Mizhnarodnoi naukovo-praktychnoi konferentsii «Ad orbem per linguas. Do svitu cherez movy», m. Kyiv, KNLU, 20-22 bereznia, 2019. Kyiv: Vyd. tsentr KNLU, 551-553.

Ming, X. Z. (2005). Developing oral presentation skills in ELT classroom. CELEA Journal, 28(2), 118-120.

Moore, D. (1994). Multimedia presentation techniques and technology. Control and Dynamic Systems, 62, 275-324.

Otoshi, J., \& Heffernen, N. (2008). Factors predicting effective oral presentations in EFL classrooms. Asian EFL Journal, 10(1), 65-78.

Robinson, M. A., Sparrow, P. R., Clegg, C., \& Birdi, K. (2005). Design engineering competencies: future requirements and predicted changes in the forthcoming decade. Design Studies, 26, 123-153. http://doi:10.1016/ j.destud.2004.09.004

Selwyn, N., \& Gordard, S. (2003). Reality bites: examining the rhetoric of widening educational participation via ICT. British Journal of Educational Technology, 34(2), 169-181.

Zareva, A. (2011). 'And so that was it': linking adverbials in student academic presentations. RELC Journal, 42(1), 515. 